\title{
Humanistic and economic burden of fibromyalgia in Japan [Corrigendum]
}

Lee LK, Ebata N, Hlavacek P, DiBonaventura M, Cappelleri JC, Sadosky A. Humanistic and economic burden of fibromyalgia in Japan. Journal of Pain Research. 2016;9:967-978.

Figures 3, 4, 5, and 6 contain errors in the key. Fibromyalgia should be dark gray and matched controls should be light gray.

The Journal of Pain Research is an international, peer reviewed, open access, online journal that welcomes laboratory and clinical findings in the fields of pain research and the prevention and management of pain. Original research, reviews, symposium reports, hypothesis formation and commentaries are all considered for publication.

\section{Dovepress}

The manuscript management system is completely online and includes a very quick and fair peer-review system, which is all easy to use. Visit http://www.dovepress.com/testimonials.php to read real quotes from published authors. 